\title{
Phraseologisms in the Political Language: An Example of Political Speeches in the German- Albanian Language Pair
}

Prof. As. Dr. Ema Kristo

Faculty of Human Sciences, "Aleksander Xhuvani" University

\begin{abstract}
The need for politics to use conflicts of interest with journalistic means in the public media often leads to the use of fixed expressions, idioms and phrases. These are used by the different social groups and parties in the public discussion, in the current dispute of opinions, and especially in the struggle for political power with different contents, interests and intentions. Starting from the fact that the political language is increasingly determined by formulaic phrases, this article presents an exemplary study of political speeches in the newspapers to explain the frequency and nature of the use of phraseologisms. Exemplary texts are the newspaper texts of the 1990s. At the center of the linguistic investigation are the changes of phrases in the text - modifications as well as obvious "violations" against the phraseological norm. Through an extensive corpus with examples from the Albanian and German daily press, the question of the role of the media in the political transformation processes is problematized and examined to what extent a crystallization of political processes takes place in phraseologisms, especially as such fixed expressions focus the specific discourses of a time.
\end{abstract}

Keywords: Phraseologisms in the Political Language. An Example of Political Speeches in the German-Albanian Language Pair 